\title{
Does gender-based leadership affect good governance in community forest management? A case study from Bhaktapur district
}

\author{
S. Thapa ${ }^{1 *}$, R. Prasai ${ }^{2}$ and R. Pahadi ${ }^{3}$
}

In spite of policy programs in place, good forest governance does not still persist in community forestry sector of Nepal. This study aims to understand how genderbased leadership affects good forest governance in the two community forest user groups, viz. the Bandeshwori CFUG and the Suryamod Perunge CFUG of Bhaktapur district, Nepal from gender perspective. Both the primary and secondary methods were employed for data collection. The collected data were screened, and analyzed qualitatively and quantitatively. The study compares the individual elements (transparency, accountability and participation) of the governance with the overall governance scenarios between the two community forests. As per the findings of this study, the female leadership was found to be better in forest management by maintaining all aspects of governance as compared to the male. This was because of the higher participation of all the users, regular audit of income and expenditure, accountability of executive committee towards user group, high-level of transparency and predictability. The study concludes that decentralization of power to female, and their active participation in leadership position are needed for maintaining good governance and proper management of community forest.

Keywords: Community Forestry, decision making, gender, good governance, leadership

$\mathrm{G}$ ood governance is considered as a peoplecentered way of managing public affairs and resources for the benefit of the entire population so that the rights of the marginalized remain central to the entire effort (Dhungana et al., 2020; Gauli \& Upadhaya, 2014; Bridgewater \& Upadhaya, 2013). As stated by the UNESCAP (2005), it has eight major characteristics, $v i z$. i) the rule of law, ii) participation, iii) consensus, iv) accountability, v) transparency, vi) responsiveness, vii) efficiency \& effectiveness, and viii) equity $\&$ inclusiveness. The main purpose of "good forest governance" is to ensure prevailing ecological processes, promoting the sustainable management of resources whilst also creating benefits economically and socially. (Paudyal et al., 2017). As community forestry is considered as the global innovation towards participatory environmental governance (Kumar, 2002), community forestry has become successful in increasing the supply of forest products, improving the environmental condition, degraded forests rehabilitation, biodiversity conservation, community development and institutionalizing democratic practices at local-level in Nepal (Dhungana et al., 2018; Stapp et al., 2015; Stapp et al. 2016). The community forestry program in Nepal has been considered as a learning ground for governance reform towards gender and equity sensitivity, governmental agencies partnership, participatory decision-making, nongovernment and private sector agencies, bottom-up planning process, participatory monitoring, and evaluation process (Pokharel \& Niraula, 2004). Till date, the total number of community forests in Nepal is 22,266 possessing $2,237,670.52$ ha land area, and more than 2,907,871 households have benefitted from this program (DoF, 2018), and are working to attain good forest governance.

Although community forestry's success has been expanded with community's participation in forest management, Wagle et al. (2016) considered forestry sector as a gendered sector,

\footnotetext{
1 Tribhuvan University, Institute of Forestry, Hetauda Campus, Makwanpur, Nepal. *E-mail: swosthinani@gmail.com

2 Wildlife, Sustainability and Ecosystem Science, Tarleton State University, Stephenville, Texas, USA; and

3 Tribhuvan University, Institute of Forestry, Hetauda Campus, Makwanpur, Nepal.
} 
which is influenced by gendered perspectives in forest resource use and sharing mechanism. Many studies conducted on community forestry in Nepal (Agarwal, 2001; Lama \& Buchy, 2002; Nightingale, 2002, 2006; Malla et al. 2003; Parajuli et al., 2010; Bhandari et al., 2018) have reported gender inequality and exclusion. Most of the forest- based decisions are made by men, which results in marginalization of women's involvement in forest management and protection, and minimizing the potential contributions of women (Christie \& Giri, 2011; Lidestav, 2010) which, in turn, is creating difficulty in attaining forest governance. Lama et al., (2017) pointed out that participation of women remained low and many of the women who were in the Executive Committees (ECs) of the CFUGs were serving as symbolic representative without exercising the authority.

Also, a growing body of work on gender and forest governance focuses on women's limited participation in management bodies and on gender equity/equality effects (Bhattarai, 2020). A study conducted by Bhandari et al. (2018) highlighted that the gender had direct impact on forest products utilization and management as women were the primary forest users with significant stakes in good forest governance. Lack of inclusive and pro-poor policy making process, inequitable benefit distribution system, inappropriate organizational structure and bottom-up planning, and unfair decision-making are some of the current governance-related issues of community forestry (Pokharel \& Niraula, 2004). Elias et al. (2017) explored that gender inequality persisted in forestry research and practice, resulting into inequitable, inefficient policies, programs, and interventions. The existence of socio-economic heterogeneity and gender inequality may lead to a failure of collective action in communal bodies (Adhikari \& Lovett, 2006; Baland et al., 2007). It has been further argued that community forestry needs good forest governance to function systematically (Pokharel \& Tiwari, 2013).

However, there have been several discussions at various areas to enhance gender perspective in community forestry governance system of Nepal. Numerous governmental and nongovernmental organizations have been playing an efficient role for improvement of participation, transparency, and accountability elements of good governance (Paudel \& Vogel, 2007). Agarwal (2009) analyzed that higher presence of women in the ECs of Forest User Groups (FUGs) showed improved forest conditions. There is a provision of $50 \%$ women representation in the EC of Community Forest User Group (CFUG), of which one key position (either chairperson or secretary) should be provided to women (Guidelines for CFDP, 2009).

Although gender perspective for governance is being promoted, FAO (2018) reported that insufficient information on the overall contribution of forests in gender equality still persists; gender-disaggregated data are required in greater extent at all levels (local, sub-national, national, regional and global) (Agarwal, 2009; Gurung et al., 2011; Bradley et al., 2013; Colfer, 2013; FAO, 2018). More than 1,000 solely women-managed community forests (CFs) exist in Nepal with female leadership (DoF, 2018); however, it is not enough to maintain women empowerment and forest governance throughout Nepal. Some studies, e.g., Lamichhane \& Parajuli (2014) and Pokhrel \& Tiwari (2013) focused on governance assessment, but the studies on gender-based leadership impacting on forest governance through gender perspective is rare in Nepal. In this context, this paper has explored the gender-based leadership's impacts on the forest governance status of two CFs of Bhaktapur district of Nepal in terms of gender perspectives through collection and comparison of the data of the two concerned CFUGs. It is a pilot case study conducted in the district, and is expected to help in fulfilling knowledge gap in gender-based forest management systems and maintaining forest governance. It would further help for development of the policies and programs to encourage women towards community forest management and reduce gender discrimination of forest users towards governance maintenance. The general objective of this study was, to assess and compare the present status of good forest governance of the two CFUGs (one solely female-managed and another managed by mixed gender but with male leadership) of the district with regards to three elements (transparency, accountability and participation level)while the specific objectives were to uncover how the ECs with different gender leadership incorporate the respective forest users of gender (male and female) categories in decision making activities in order to maintain good governance. 


\section{Materials and methods Study area}

The study was carried out in the two the Community Forest User Groups (CFUGs), viz. Bandeshwori CFUG and Suryamod Perunge CFUG of Bhaktapur district which lies in the eastern part of the Kathmandu valley situated in the central mid-hill region of Nepal (Figure 1). It is located between $27^{\circ} 36^{\prime}-27^{\circ} 44^{\prime} \mathrm{N}$ latitudes and $85^{\circ} 21^{\prime}-85^{\circ} 32^{\prime} \mathrm{E}$ longitudes , and the terrain ranges from $1,331 \mathrm{~m}$ to $2,191 \mathrm{~m}$ above the mean sea level. Bhaktapur,the smallest district among all the 77 districts of Nepal, extends over an area of 11,900 ha of which 1,253 ha $(29.6 \%$ of the total forest area of Nepal (DFRS, 2018); out of this total forest area, 4,232 ha lies within the Suryabinayak Municipality alone. So far, 56 CFs have been handed over to the concerned CFUGs within the district. The Bandeshwori $\mathrm{CF}$, with the area of 55.36 ha and lying within the Suryabinayak Municipality-10, is solely a female managed $\mathrm{CF}$ of the district. It was handed over to the concerned CFUG in 2058 B.S., and is providing benefits to 253 households ( $\mathrm{HHs}$ ) in the locality. On the other hand, the Suryamod Perunge CF, with the area of 24.1 ha and situated in Suryabinayak Municipality- 8 of the district, is purely a male-headed CF. It was handed over to the concerned CFUG in 2056 B.S., and is benefitting $128 \mathrm{HHs}$. The district is inhabited by diverse ethnic groups of people with different socio-economic backgrounds. So, both the CFUGs consist of different caste of users such

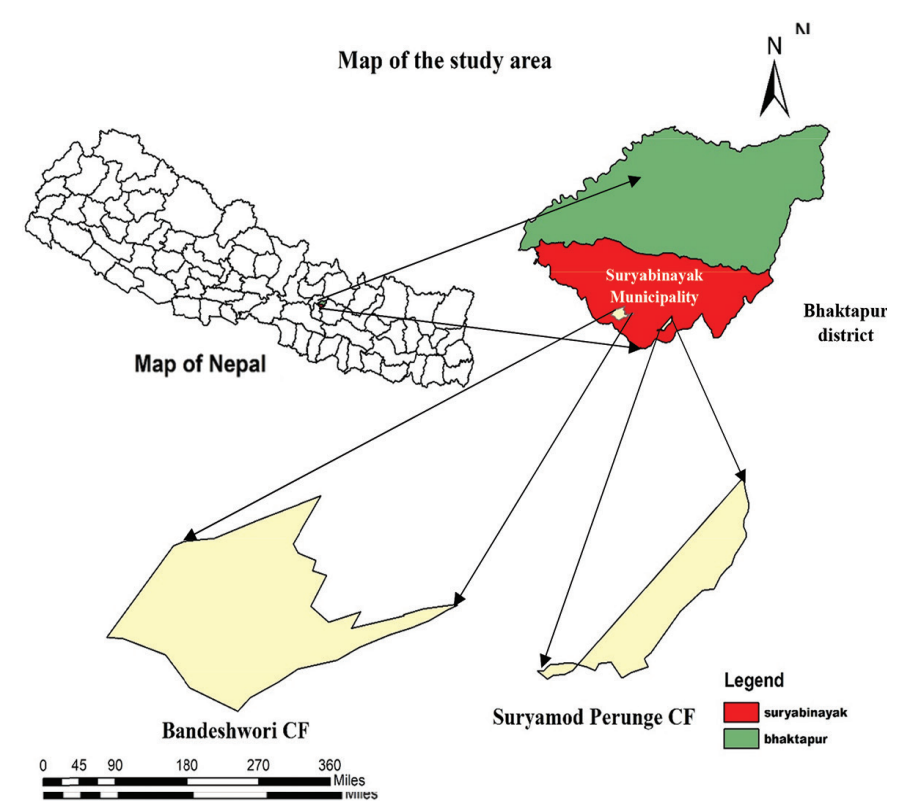

Fig. 1: Map showing the locations of the study areas as Brahmin, Chhettri, Newar and other Janajatis (nationalities), and Dalits (socially backward groups of people) as their members.

In both the CFs, the principal species found are Rani Salla (Pinus roxburghii), Utis (Alnus nepalensis), Katus (Castanopsis indica), Chilaune (Schima wallichii) and Gurans (Rhododendron arboreum) together with Nigalo (Drepanostachyum falcatum).

\section{Data collection}

The data were collected from the CFUGs through structured and semi-structured questionnaire. The primary information were collected from key informant surveys, household surveys, personal observations, and focus group discussions while the secondary information were acquired from the District Forest Office reports, the respective operational plans (OPs) of the two studied CFs, the constitutions of the concerned CFUGs and their minute-books together with the financial and administrative records, research reports and journal-articles.

For household survey, stratified random sampling with a sample of $15 \%$ total households from every well-being class (rich, medium and poor) of both the CFs was carried out. Altogether, $39 \mathrm{HHs}$ (with 2-rich, 35-medium, and 2-poor) of the total 253 HHs (with 8-rich, 234-medium, and 11-poor) of the Bandeshwori CFUG were selected for interview. Similarly, $20 \mathrm{HHs}$ (with 5-rich, 11-medium, and 4-poor) of the total $128 \mathrm{HHs}$ (with 28-rich, 70-medium, and 30-poor) of the Suryamod Perunge CFUG were selected for the purpose. On the other hand, focus group discussions (FGDs) were organized with the Community Forest User Committees (CFUCs) and the women groups to discuss on various topics, such as FUG operation procedure, information flow mechanism, decision making, participation level, record keeping system, forest harvesting, management and protection, transparency, accountability, responsibility, and so on. Apart from the FGDs, key informant survey was also conducted with the excommittee members, village leaders, forest watchmen, social workers, local elites and school teachers. Furthermore, personal observations were also done during the study period and all types of meetings. 


\section{Developing criteria and indicators}

The assessment of forest governance in this study centered on the Program on Forest (PROFOR, 2011)/FAO's Framework for Assessing and Monitoring Forest Governance; and PROFOR Assessing and Monitoring Forest Governance diagnostic tool (Kishor and Rosenbaum, 2012) which identifies good forest governance in the circumstance of large range of various actors with different requirements. The framework determines six principles, viz. (i) transparency, (ii) participation, (iii) efficiency, (iv) accountability, (v) effectiveness, and (vi) fairness/equity cutting across three pillars of governance, viz. (i) Policy, legal, institutional and regulatory frameworks (i.e. how legislation, policies and institutions look on paper); (ii) planning and decision-making processes (i.e., how people plan and make decisions); and (iii) implementation, enforcement and compliance (i.e., how things work out practically).

For the study of good forest governance in Bhaktapaur district, the number of indicators from this assessment tool were reduced and added based on the local relevance, availability of quality information, and adjusted for scoring the indicators to reflect local conditions or issues. Our study focused only on 3 principles/criteria (transparency, accountability and participation) and 14 indicators (5 under participation, 5 under transparency, and 4 under accountability) of the tool. A scoring scale of indicators (poor-1, fair-2, good-3, and excellent-4) were developed (Table 1).

Table 1: Criteria and indicators for governance assessment

\begin{tabular}{|c|c|}
\hline $\begin{array}{l}\text { Criteria/ } \\
\text { Elements }\end{array}$ & Indicators \\
\hline Transparency & $\begin{array}{l}\text { i. Ratio of CFUG members who } \\
\text { know about source of income and } \\
\text { expenditure of CFUG; } \\
\text { ii. Transparency on forest product } \\
\text { distribution system and its } \\
\text { allocation; } \\
\text { iii. Regular practice of public audit } \\
\text { process, details discussion and } \\
\text { approved by concerned public/ } \\
\text { users; } \\
\text { iv. CFUG's annual programs, progress, } \\
\text { budget and other information are } \\
\text { approved by the users that is made } \\
\text { public through community notice } \\
\text { boards and other best means; and } \\
\text { v. Transparency in decision making. }\end{array}$ \\
\hline
\end{tabular}

\begin{tabular}{|c|c|}
\hline $\begin{array}{l}\text { Criteria/ } \\
\text { Elements }\end{array}$ & Indicators \\
\hline Participation & $\begin{array}{l}\text { i. Active participation of users in } \\
\text { general assembly, meetings, OP/ } \\
\text { constitution preparation/renew; } \\
\text { ii. Regular following of participatory } \\
\text { decision making process, and } \\
\text { bottom-up planning; } \\
\text { iii. Full attendance in forest product } \\
\text { distribution related meetings, and } \\
\text { CF activities; } \\
\text { iv. Purposeful and regular engagement } \\
\text { of women and socially backward } \\
\text { people in every general assembly/ } \\
\text { meeting and consideration of their } \\
\text { voice; and } \\
\text { v. Decision in benefit sharing and need } \\
\text { analysis. }\end{array}$ \\
\hline Accountability & $\begin{array}{l}\text { i. Ratio of users following their } \\
\text { roles, responsibilities and duties; } \\
\text { ii. Attendance of the CFUC and CFUG } \\
\text { members on time in meetings and } \\
\text { assembly; } \\
\text { ii. Accountability of CFUG/CFUC } \\
\text { for implementation of women, } \\
\text { poor and dalit development } \\
\text { program; and } \\
\text { iv. Provision for performance-based } \\
\text { reward and penalties. }\end{array}$ \\
\hline
\end{tabular}

\section{Calculation of governance index}

For statistical analysis of good governance, a sequence of calculations were conducted methodologically. Response from every respondent of both the CFUGs, considering the criteria/elements and indicators, were obtained for further analysis. The governance status in each CFUG was calculated using the simple formula:

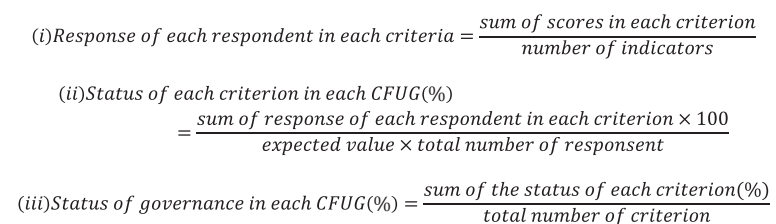

(Lamichhane \& Parajuli, 2014).

The expected value for each indicator was taken as 4 because it was the highest value in scoring scale of indicators. The overall performance was estimated on the basis of the weighted average of the percentage scores (Table 2) of all the criteria to determine the governance status and the areas for improvement. 
Table 2: Evaluation of performance on good governance

\begin{tabular}{|c|c|l|}
\hline Score range (\%) & Status & \multicolumn{1}{|c|}{ Remarks } \\
\hline $85-100$ & Very good & Keep it up \\
\hline $65-84$ & Good & Still room for improvement \\
\hline $50-64$ & Medium & Still plenty of rooms for improvement \\
\hline $35-63$ & Poor & Needs more effort and commitment to improve \\
\hline$<35$ & Very poor & Needs major reforms \\
\hline
\end{tabular}

Source: (Gyawali \& Subedi, 2011).

The status of the participation of the users in decision making was accomplished through Pearson Chi-square test, and the information was interpreted for gender category which played great role in the objective of the study.

\section{Results \\ Governance status in elements of the CFUGs}

The indicators for individual elements of good forest governance were scored on the basis of obtained information from the users of CFs. The score of indicators of each CFUG from the individual selected respondents were analyzed properly. Along with the descriptive analysis of each element, a sequence of calculations were conducted for statistical analysis based on the simple mathematical procedure for calculating the governance explained earlier.

The values thus calculated following the mathematical procedure is explained in the form of bar graph in Figure 2 which shows the status of all the three elements of good governance for both the CFUGs. The status of the elements of the Bandeshwori CFUG under female leadership was found to be higher with $84 \%$ on transparency, $85 \%$ on accountability and $88 \%$ on participation as compared to that of the Suryamod Perunge CFUG under male leadership with $64 \%$ on transparency, $63 \%$ on accountability and $60 \%$ on participation (Figure 2). The performance of each element on the basis of the criteria highlighted in Table 2 indicated that the level of the accountability and participation elements of the Bandeshwori CFUG were found to be "very good" and that of transparency "good" whereas in the case of Suryamod Perunge CFUG, all the three elements were found to be at medium-level, and they still required plenty of rooms for improvement.

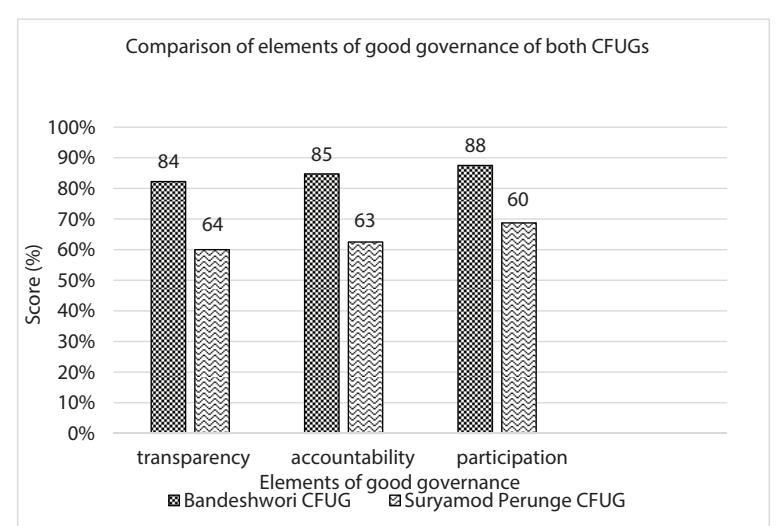

Fig. 2: Governance status in the CFUGs

\section{Overall governance status in the CFUGs}

After analyzing and comparing the status of each element of governance, the overall governance of each CFUG was assessed following the mathematical procedure. The weight score of all the three elements (which indicated the overall governance status) of the Bandeshwori CFUG was found to be $85 \%$, while it was only $62 \%$ in the case of the Suryamod Perunge CFUG (Figure 3 ), which clearly indicated that the overall governance status of the later one needed more improvement so as to increase it to the level of the former one.

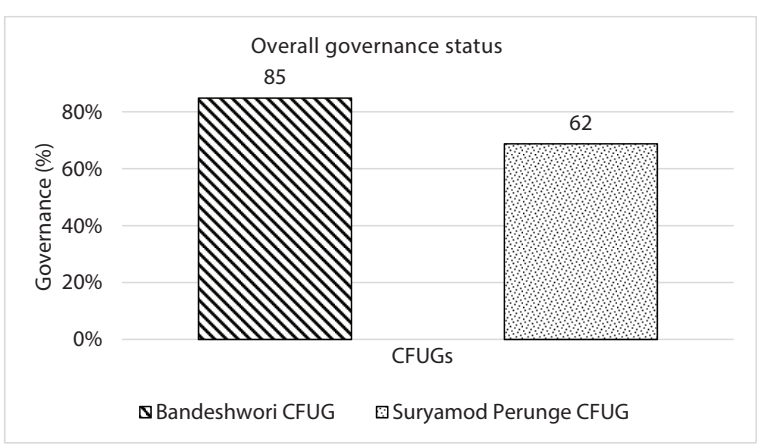

Fig. 3: Overall governance status in the CFUGs 


\section{Participation of the CFUG users in decision making on forest-related activities}

On the basis of the objective of the study, the status of decision making (which was influenced by the gender category ultimately affecting the forest governance) in both the CFUGs were analyzed. All the female users of the Bandeshwori CFUG were involved in decision making activities because of which the calculation of gender consideration was not included here, but the Suryamod Perunge CFUG had gender-related issues in decision making. In the case of Suryamod Perunge CFUG, the involvement of the male users in all the forest-related decision making activities was from medium to high whereas that of the female was either nil or just medium, lacking their higher involvement (Table 3).

Table 3: Participation of Suryamod Perunge CFUG members in decision making on forest-related activities

\begin{tabular}{|c|c|c|c|c|c|}
\hline \multirow{2}{*}{ Decision making on } & \multirow{2}{*}{ Gender } & \multicolumn{4}{|c|}{$\begin{array}{c}\text { Participation of CFUG } \\
\text { members }(\%)\end{array}$} \\
\hline & & No & Low & Medium & High \\
\hline \multirow{2}{*}{$\begin{array}{l}\text { Forest management activities (silvicultural and } \\
\text { harvesting activities, forest protection and fire } \\
\text { line construction, forest block division, proper OP } \\
\text { implementation and monitoring, management plans and } \\
\text { implementation) }\end{array}$} & Male & 0 & 0 & 10 & 30 \\
\hline & Female & 20 & 25 & 15 & 0 \\
\hline \multirow{2}{*}{$\begin{array}{l}\text { Resource utilization activities (sustainable resource } \\
\text { collection and utilization, pricing of forest products, } \\
\text { fund mobilization for various forestry and community } \\
\text { activities, fund allocation for capacity development, } \\
\text { IGA) }\end{array}$} & Male & 0 & 0 & 15 & 25 \\
\hline & Female & 15 & 30 & 15 & 0 \\
\hline \multirow{2}{*}{$\begin{array}{l}\text { Participatory activities (users identification, female's } \\
\text { inclusion, CFUC formation, general assembly/monthly } \\
\text { meetings, OP preparation, participatory forest product } \\
\text { distribution, appropriate time selection to enter in the } \\
\text { forest for silvicultural purpose) }\end{array}$} & Male & 0 & 0 & 15 & 25 \\
\hline & Female & 10 & 20 & 30 & 0 \\
\hline
\end{tabular}

The low participation ratio of the female users compared to the male ones of the Suryamod Perunge CFUG in decision making was determined through Chi-square test (Table 5). It was hypothesized that "the involvement of the forest users in decision making on forest-related activities was associated with gender of the users". The observed and expected values of the various forestry activities of both the genders at participation-level are highlighted in Table4. In the case of forest management activity, the calculated Chi-square value (15.0) was found to be greater than the tabulated one (7.815) at 0.05 significance level with 3 degrees of freedom, which was further supported by the lower p-value of 0.002 (Table 5). Similarly, the calculated Chi-square values of the resource utilization and participatory activities were 13.75 and 11.67 , respectively, which were higher than the tabulated ones (7.815). Also, the p-values (0.003 and 0.009) for both the respective activities were lower at 0.05 level of significance. Therefore, the null hypothesis (no association between gender and forestry activities) was rejected, and it came to be true that, in the case of the Suryamod Perunge CFUG, the involvement of the forest users in decision making on forestrelated activities was highly dependent on gender of the users. Generally, the males were favored in decision making on the forest-related activities while the females were discarded from such activities even if they were primary users of the forest resources. On the contrary, the female users of the Bandeshwori CFUG were involved in decision making activities too, which was, no doubt, supported by its governance status. 
Table 4: Observed and expected values of the extent of participation of Suryamod Perunge CFUG members in different forestry activities

\begin{tabular}{|c|c|c|c|c|c|}
\hline \multirow{3}{*}{$\begin{array}{l}\text { Forestry } \\
\text { activities }\end{array}$} & \multirow{3}{*}{$\begin{array}{c}\text { Extent of } \\
\text { participation }\end{array}$} & \multicolumn{4}{|c|}{ Gender } \\
\hline & & \multicolumn{2}{|c|}{ Male } & \multicolumn{2}{|c|}{ Female } \\
\hline & & $\begin{array}{c}\text { Observed } \\
\text { values }\end{array}$ & $\begin{array}{c}\text { Expected } \\
\text { values }\end{array}$ & $\begin{array}{c}\text { Observed } \\
\text { values }\end{array}$ & $\begin{array}{c}\text { Expected } \\
\text { values }\end{array}$ \\
\hline \multirow{4}{*}{$\begin{array}{l}\text { Forest } \\
\text { management }\end{array}$} & No & 0 & 1.6 & 4 & 2.4 \\
\hline & Low & 0 & 2.0 & 5 & 3.0 \\
\hline & Medium & 2 & 2.0 & 3 & 3.0 \\
\hline & High & 6 & 2.4 & 0 & 3.6 \\
\hline \multirow{4}{*}{$\begin{array}{l}\text { Resource } \\
\text { utilization }\end{array}$} & No & 0 & 1.2 & 3 & 1.8 \\
\hline & Low & 0 & 2.4 & 6 & 3.6 \\
\hline & Medium & 3 & 2.4 & 3 & 3.6 \\
\hline & High & 5 & 2.0 & 0 & 3.0 \\
\hline \multirow{4}{*}{$\begin{array}{l}\text { Participatory } \\
\text { activities }\end{array}$} & No & 0 & 0.8 & 2 & 1.2 \\
\hline & Low & 0 & 1.6 & 4 & 2.4 \\
\hline & Medium & 3 & 3.6 & 6 & 5.4 \\
\hline & High & 5 & 2.0 & 0 & 3.0 \\
\hline
\end{tabular}

Table 5: Chi-square values of different variables in Suryamod Perunge CFUG

\begin{tabular}{|c|c|c|c|c|c|c|}
\hline \multirow{2}{*}{$\begin{array}{c}\text { Independent } \\
\text { variables }\end{array}$} & \multicolumn{6}{|c|}{ Forestry activities } \\
\cline { 2 - 7 } & \multicolumn{2}{|c|}{ Forest management } & \multicolumn{2}{|c|}{ Resource utilization } & \multicolumn{2}{c|}{ Participatory activities } \\
\cline { 2 - 7 } & Chi-square & p-value & Chi-square & p-value & Chi-square & p-value \\
\hline Gender (male/female) & 15.00 & $0.002 *$ & 13.75 & $0.003^{*}$ & 11.67 & $0.009^{*}$ \\
\hline
\end{tabular}

*at $5 \%$ level of significance with 3 degrees of freedom.

\section{Discussion}

Our study has considered gendered perspective towards forest governance of the two CFs of Bhaktapur district of Nepal, selected on genderbased leadership. The study indicated that women's participation and leadership had great influence on governance status of forest, which would directly affect forest management. The womenmanaged CFUG, i.e. the Bandeshwori CFUG did not have any gender-related issues as all the ECmembers and forest users were female, and all of them were involved in forest-related activities as well as capacity building and decision making, which, no doubt, helped to maintain good forest governance. Besides, the income and expenditure were always audited, forest products distributed systematically, and all the information were kept transparent through notices, informal messages and meetings. Our study supports study of Buchy
\& Rai (2008) who reported that women-only CFUGs has contributed towards maintenance of governance (transparency, communication and accountability) including forest cover management and financial improvement. Also, Leisher et al. (2016) suggested that women empowerment in decision making roles has great importance in better governance of natural resources. The studies of Agarwal $(2009,2010)$ in Nepal and India reported that improvement in forest governance and resource sustainability were directly correlated with women's involvement in forest management executive committees, and decision making in rule enforcement.

Although there is a provision of $50 \%$ women representation in male-headed CFUG, they are less favored for active involvement. Wagle et al. (2016) stated that in Nepal, achievements in preparation of women-friendly policies 
and practices in community-based forestry institutions are only in paper, and lacked in application towards overall governance of forestry sector. Instead of achieving genuine influence in decision making process, increase of women's memberships in decision-making bodies are only for fulfilling official gender-equity quota described by the governmental policies (Bhattarai, 2020). Key positions in CFUCs are essential as their individual involvement in the respective field has greater importance, and they hold some kind of authority. Despite being in one of the key positions (secretary) in the case of the Suryamod Perunge CFUC, female were excluded in decision making process, which in turn decreased the overall performance of the CFUG. Our study contradicts the findings done by Acharya \& Gentle (2006) who noted positive changes because of women's key decision making positions in community forest user groups in Nepal. Women are generally under-represented in forest user groups (Coleman \& Mwangi, 2013).

It was reported that the users, especially women, hardly participated in the meetings and assemblies of the Suryamod Perunge CFUG unless they received direct benefits which made meetings irregular and inactive. There was a lack of accountability among the users and committee members. The women were mostly excluded by men from major forest activities, meetings, product distribution and decision making. In reporting a similar situation, Poudel (2003) concluded that women's presence in committee meetings and discussions was only for attendance to record on the minute books and not for suggestions and decision making in different activities. Women were highly excluded from decision making because of limited access to required information and norms, lack of women's representation and their recognized role in public forums (Agarwal, 2002);also, the decisions are done without seeking the agreement of the female members (Giri \& Darnhofer, 2010; Lama \& Buchy, 2002). Despite the fact that some remarkable efforts towards policies and practices, e.g., in CF operational plan, practice of auditing and reporting of funds, and maintenance of minute books had been made in the male-headed Suryamod Perunge CFUG, these achievements were not reflected in the overall forest governance. The decisions were self-oriented and were made mainly by male CFUC. Despite the fact that both male and female have equal ability to create positive change in the institution in their favor, there is difficulty in achieving change due to women's lower-level of power resources in the institution ( Samndong \& Kjosavik, 2017). If gender isn't taken into account in policy research and implementation, it highly affects forestry planning, distort understanding of human impacts on resource management and alter resource allocation thus negatively affecting potential opportunities for successful policy implementation (FAO, 2007).

For ensuring proper forest management, there is necessity of women encouragement, enhance their pro-activeness and increase participation in decision making process. However, the forgotten initial step for gender-inclusive community forests management might be developing appropriate social space for female members in every public decision making bodies (Bhattarai, 2020).Although policies and programs have favored in increment of women representatives in community forestry EC and general assemblies, there is necessity of their effective participation at all-levels (Agarwal, 2010; Lama \& Buchy, 2002). There is a strong need to revive the work on gender relations, identities, and responsibilities (Tyagi \& Das, 2017).

Numerous important issues have been identified from this pilot case study on the community forestry status in Nepal in relation to gender and good forest governance. Firstly, women are well presented in participatory decision making only in solely women-managed CFUGs while women are generally dominated as well as deprived from such activities in CF managed by mixed gender. Secondly, good forest governance can only be maintained when effective participation of women in forestry is encouraged. Thirdly, regular research and monitoring of application of policies and further exploration in other elements play vital role for proper women representation and governance maintenance in CFs.

\section{Conclusion}

Among the community forest users, females are primary users of forest resources, so gender is important factor in maintaining governance. While comparing the elements and overall governance status of the two CFUGs, the study revealed that the female-headed CFUGs was better in forest management in terms of all aspects of governance as compared to the one under male 
leadership. It can be, therefore, concluded that decentralization of power to female users and their active participation in leadership position are needed for maintaining good governance and proper management of community forests. Besides, regular studies with more sample size and techniques are required for maintaining forest governance in community forestry.

\section{Acknowledgements}

We express our gratitude to all the CFUC and CFUG members of both the Bandeshworiand Suryamod Perunge CFs for their cooperation during our field visits and data collection. Also, we are grateful to the District Forest Office, Bhaktapur for providing valuable information.

\section{References}

Acharya, K. P., and Gentle, P. (2006). Improving the effectiveness of collective action: Sharing experiences from community forestry in Nepal. CAPRI Working Paper No. 54. Proceedings of International Research Workshop on Gender and Collective Action. Chiang Mai, Thailand.

Adhikari, B. \& Lovett, J. (2006). Institutions and collective action: does heterogeneity matter in community-based resource management? Journal of Development Studies 42 (3): 426-445.

Agarwal, B. (2001). Participatory exclusions, community forestry and gender: an analysis and conceptual framework. World Development 29 (10): 1623-1648.

Agarwal, B. (2002). The hidden side of group behavior: a gender analysis of community forestry in south Asia. In Group behavior and development: Is the market destroying cooperation? J . Heyer, Stewart, and R. Thorp (Eds.) Oxford University Press, Oxford, United Kingdom, 185-208.

Agarwal, B. (2009). Gender and forest conservation: The impact of women's participation in community forest governance. Ecological Economics 68 (11): 2785-2799. https://doi:10. 1016/j. ecolecon. 2009. 04. 025
Agarwal, B. (2010). Does women's proportional strength affect their participation? Governing local forests in South Asia. World Development 38 (1): 98-112. https:// doi:10. 1016/j. worlddev. 2009. 04. 001

Baland, J., Bardhan, P., \& Bowles, S. (2007). Inequality, Cooperation, and Environmental Sustainability. Princeton, NJ: Russell Sage Foundation, Princeton University Press.

Bhattarai, B. (2020). How do gender relations shape a community's ability to adapt to climate change? Insights from Nepal's community forestry. Climate and Development 12 (10): 876-887. https:// doi:10. 1080/17565529. 2019. 1701971

Bradley, A., Setyowati, A. B., Gurung, J., Yeang, D., Net, C., Khiev, S. \& Brewster, J. (2013). Gender and REDD+: an assessment in the OddarMeanchey Community Forestry REDD+ Site, Cambodia. Phnom Penh (Cambodia): PACT Cambodia and WOCAN.

Bridgewater, P. \& Upadhaya, S. (2013). Model Forest and its prospect in Nepal. The Initiation 4: 120-124.

Buchy, M. \& Rai, B. (2008). Do women-only approaches to natural resource management help women? The case of community forestry in Nepal. In Gender and natural resources management:livelihoods, mobility, and interventions. B. P. Resurreccion \& R. Elmhirst (Eds.). Earthscan, Oxford, England.

Christie, M. E. \& Giri, K. (2011). Challenges and experiences of women in the forestry sector in Nepal. International Journal of Sociology and Anthropology 3 (5): 139146. http://www. academicjournals. org/ ijsa

Coleman, E. A. \& Mwangi, E. (2013). Women's participation in forest management: a crosscountry analysis. Global Environmental Change 23:193-205. http://dx. doi. org/10. 1016/j. gloenvcha. 2012. 10. 005

Colfer, P. J. C. (2013). The gender box: A framework for analyzing gender roles in 
forest management. Bogor (Indonesia): Center for International Forestry Research (CIFOR).

DFRS. 2018. Forest Cover Maps of Local Levels (753) of Nepal. Department of Forest Research and Survey (DFRS), Kathmandu, Nepal.

Dhungana, N., Silwal, N., Upadhaya, S., Khadka, C., Regmi, S. K., Joshi, D. \& Adhikari, S. (2020). Rural coping and adaptation strategies for climate change by Himalayan communities in Nepal. Journal of Mountain Science 17 (6): 1462-1474. https://doi. org/https://doi. org/ 10. 1007/s 11629-019-5616-3

Dhungana, N., Silwal, N., Upadhaya, S., Regmi, S. K. \& Adhikari, S. (2018). Local people's perception and awareness of climate change: a case study from community forests in Lamjung District, Western Nepal. BankoJanakari 28: 60-71. https:// doi. org/https://doi. org/ 10. 3126/banko. v28i2. 24189

DoF. (2018). Database on Community Forests in Nepal. Department of Forests, Ministry of Forests and Soil Conservation, Kathmandu, Nepal.

Elias, M., Hummel, S. S., Basnett, B. S. \& Colfer, C. J. P. (2017). Gender bias affects forests worldwide. Ethnobiology Letter 8 (1): $31-$ 34. https://doi. 10. 14237/ebl. 8. 1. 2017. 834

FAO. (2007). Gender mainstreaming in forestry in Africa. Forestry Policy and Institution Working Paper.

FAO. (2018). The state of the world's forests- Forest pathways to sustainable development. Rome (Italy): Food and Agriculture Organization of the United Nations (FAO).

Gauli, B. \& Upadhaya, S. 2014. Reducing emissions from deforestation and forest degradation (REDD) in Nepal: A review. The Initiation 5: 75-83. https://doi. org/ http://dx. doi. org/10. 3126/init. v5i0. 10257
Giri, K. \& Darnhofer, I. (2010). Nepali women using community forestry as a platform for social change. Society \& Natural Resources 23 (12): 1216-1229. https:// doi:10. 1080/08941921003620533

Guidelines for CFDP. (2009). Guidelines for Community Forestry Development Program (Second Revision). Community Forestry Division, Department of Forests, Babarmahal, Kathmandu, Nepal.

Gurung, A., Karki, R. \& Bista, R. (2011). Community-based forest management in Nepal: opportunities and challenges. Resources and Environment 1 (1): 26-31.

Gyawali, A. \& Subedi, M. (2011). Assessing the governance: Participation and transparency perspective. Prathat Journal. Vol. 16. https://www. researchgate. net/ publication/265000561 Assessing the_Governance_Participation_and_ Transparency_Perspective

Kishor, N. \& Rosenbaum, K. (2012). Assessing and Monitoring Forest Governance: A User's Guide to a Diagnostic Tool; PROFOR: Washington, DC, USA, ISBN 978-0-9855195-2-0. https://www. profor. info/sites/profor. info/files/AssessingMoni toringForestGovernance-guid e. pdf

Kumar, S. (2002). Methods for Community Participation. A Complete Guide for Practitioners. London: ITDG Publishers.

Lama, A. \& Buchy, M. (2002). Gender, class, caste and participation: the case of community forestry in Nepal. Indian Journal of Gender Studies 9 (1): 27-41.

Lama, A., Kharel, S. \& Ghale, T. (2017). When the men are away: migration and women's participation in Nepal's community forestry. Mountain Research and Development 37 (3): 263-270.

Lamichhane, D. \& Parajuli, R. (2014). How good is the governance status in community forestry? A case study from mid-hills in Nepal. Journal of Ecosystems. http://dx. doi. org/10. 1155/2014/541374 
Leisher, C., Temsah, G., Booker, F., Day, M., Samberg, L., Prosnitz, D. \& Wilkie, D. (2016). Does the gender composition of forest and fishery management groups affect resource governance and conservation outcomes? A systematic map. Environmental Evidence 5 (1): $1-10$.

Lidestav, G. (2010). In competition with a brother: Women's inheritance positions in contemporary Swedish family forestry. Scandinavian Journal of Forest Research 25 (9): 14-24.

Malla, Y. B., Neupane, H. R. \& Branney, P. (2003). Why aren't poor people benefiting more from community forestry? Journal of Forests and Livelihood 3 (1): 78-93.

Nightingale, A. J. (2002). Participating or just sitting in? The dynamics of gender and caste in community forestry. Journal of Forest and Livelihood 2, 1.

Nightingale, A. J. (2006). The nature of gender: work, gender and environment. Society and Space. 24 (2):165-185.

Parajuli, R., Pokharel, R. K. \& Lamichhane, D. (2010). Social discrimination in community forestry: socio-economic and gender perspectives. Banko Janakari 20 (2): 26-33.

Paudel, A. \& Vogel, S. (2007). Community forestry governance in Nepal: a case study of the role of service providers in a community forest users group. DP-342007, University of Natural Resource and Applied Life Sciences, Vienna, Austria, 2007. https://wpr. boku. ac. at/wpr_dp/ DP34-2007. pdf.

Paudyal, K., Baral, H., Lowell, K. \& Keenan, R. J. (2017). Ecosystem services from community-based forestry in Nepal: realizing local and global benefit. Land Use Policy2017 (63):342-355.

Pokharel, B. K. \& Niraula, D. R. (2004). "Community forestry governance in Nepal: achievements, challenges \& options for the future". In Proceedings of the 4th national workshop on community forestry, twenty-five years of community forestry. K. R. Kanel, P. Mathema, B. R. Kandel, D. R. Niraula, A. R. Sharma \& M. Gautam (Eds.). Kathmandu, Nepal. pp. 298-316.

Pokharel, R. K., \& Tiwari, K. R. (2013). Good governance assessment in Nepal's community forestry. Journal of Sustainable Forestry32 (6): 549-564.

Poudel, B. S. (2003). The rural poor and the forest resources: socioeconomic heterogeneity, benefit sharing and participation in community forest in Nepal. M. Sc Thesis. Tribhuvan University, Institute of Forestry, Pokhara, Nepal.

PROFOR. (2011). Framework for Assessing and Monitoring Forest Governance: The Program on Forests. Food and Agriculture Organization of the United Nations (FAO), Rome, Italy. https:// www. fao. org/climatechange/275260cc61ecc084048c7a9425f649 42df70a8. pdf

Samndong, R. A. \& Kjosavik, D. J. (2017). Gendered forests: exploring gender dimensions in forest governance and REDD+ in Équateur Province, Democratic Republic of Congo (DRC). Ecology and Society 22 (4):34. https://doi. org/10. 5751/ ES-09753-220434

Stapp, J. R., Lilieholm, R. J., Leahy, J. \& Upadhaya, S. (2016). Linking Attitudes, Policy, and Forest Cover Change in Buffer Zone Communities of Chitwan National Park, Nepal. Environment Management 57. https://doi. org/10. 1007/s00267-0160682-6

Stapp, J. R., Lilieholm, R. J., Upadhaya, S. \& Johnson, T. (2015). Evaluating the impacts of forest management policies and community-level institutions in the buffer zone of Chitwan National Park, Nepal. Journal of Sustainable Forestry. https://doi. org/10. 1080/10549811. 2015. 1025080

Tyagi, N. \& Das, S. (2017). Gender mainstreaming in forest governance: 
analyzing 25 years of research and policy in South Asia. International Forestry Review 19:234-244. https://dx. doi. org/10. 1505/146554817821255132

UNESCAP. (2005). What is Good Governance? United Nations Economic and Social Commission for Asia and the Pacific. https://www. unescap. org/huset/gg/ governance. html (accessed on November $8,2005)$.

Wagle, R., Pillay, S. \& Wright, W. (2016). Examining Nepalese forestry governance from gender perspectives. International Journal of Public Administration40 (3): 205-225. 